107, 308-14 (1960).

4) G.A. Slack, J. Phys. Chem. Solids, 34, 321-35 (1973).

5) T. Sakai, Yogyo-Kyokai-Shi, 86, 335-40 (1978).

6) The TPRC Data Series, Thermophys. Properties of Matter, Vol. 5, Plenum, N.Y. (1970).

7) JANAF, Thermochemical Table, 2nd. ed. (1971) Horikosi Lab., Tokyo.
8) T. Tanaka, T. Sakai and M. I wata, Yogyo-KyokaiShi, 81, 399-400 (1973).

9) T. Sakai and M. Iwata, J. Mater. Sci., 12, 1659-65 (1977).

10) R.L. Coble, J. Appl. Phys., 32, 787-92 (1961).

11) R.L. Coble, ibid., 41, 4798-807 (1970).

12) W.D. Kingery, J. Am. Ceram. Soc., 37, 42 (1954).

論文・Paper

\title{
ボーンチャイナ素地の焼成過程
}

\author{
市古忠利 \\ (鸣海製陶 (株) 研究空)
}

骨リンを使用したボーンチャイナの製造のための基礎資料を得ることを目的に，ボーンチャイナ 素地の焼成過程を等温収縮の測定及びX線回折, 偏光顕微鏡, 走査型電子顕微鏡による観察によっ て速度論的, 微構造的に考察した。 また燒成素地のかさ比重, 弾性率, 抗折強度, 透光度, 膨張係 数も測定した.

昇温熱膨張収縮の結果から $920^{\circ} \mathrm{C}$ 付近と $1200^{\circ} \mathrm{C}$ 付近に明確な収縮が認められた. $920^{\circ} \mathrm{C}$ 付近 の収縮は拡散反応機構によると推測できた。 $1200^{\circ} \mathrm{C}$ 付近の収縮は粘性流動機構と結晶の溶解過程 の複合した収縮過程と推測できた。弾性率と抗折強度は $1200^{\circ} \mathrm{C}$ 以上でマトリックス部の溶融相の 発達に伴い増大し, 気孔の発達に伴い減少した. 透光度はマトリックス部の溶融相の発達に伴い増 大し, 膨張係数は結晶の溶解に伴い減少した。

骨リンを使用した素地と骨灰を使用した素地を比較すると， $920^{\circ} \mathrm{C}$ 付近の $\mathrm{Ca}_{3}\left(\mathrm{PO}_{4}\right)_{2}$ とアノー サイトの生成過程の違いを除いては, 焼き締り過程, 微構造, 焼成素地の特徵に顕著な差違は認め られなかった。

(1977 年 9 月 29 日受付)

\section{Firing Process of Bone China Bodies}

\author{
Tadatoshi ICHIKO
}

(Narumi China Corporation, Nagoya-shi, 458)

In order to collect fundamental data for manufacturing bone china by using bone phosphate, firing process of bone china bodies was investigated by conventional methods kinematically and microscopically. And bulk specific gravity, modulus of elasticity, transverse strength, translucency, and expansion coefficient for fired bodies were measured.

The results of linear thermal expansion and shrinkage in the specimens showed two distinct stages which shrinked at about $920^{\circ} \mathrm{C}$ and $1200^{\circ} \mathrm{C}$ or higher temperature. The shrinkage occurred at about $920^{\circ} \mathrm{C}$ seemed to accompany with diffusion sintering process. The shrinkage observed at about $1200^{\circ} \mathrm{C}$ might be related to the densification process occurred by both viscous flow mechanism and melting process of crystal grains in bodies. Modulus of elasticity and transverse strength increased with spreading of melt through matrix phase and decreased with expansion of the pores at $1200^{\circ} \mathrm{C}$ or higher temperature. Translucency increased with spreading of melt through matrix phase and expansion coefficent decreased with melting of crystals.

In comparison with bone china body of using bone phosphate and that of using bone ash, the vitrification behaviour, microstructure, and natures of fired bodies were not so markedly 
chaged except the process of producing $\mathrm{Ca}_{3}\left(\mathrm{PO}_{4}\right)_{2}$ and anorthite at about $920^{\circ} \mathrm{C}$.

[Received September 29, 1977]

\section{1. 緒言}

ボーンチャイナを骨灰を用いずに，セラチン製造工程 で副生する骨リンを用いて製造するための基礎研究を行 った，骨灰を用いた素地の研究はいくつか報告されてお $り^{12,2)}$ ，また骨リンを用いた素地の焼成反応については 既に著者らが報告した ${ }^{3) \sim 5)}$. 今回は骨リン使用素地と骨 灰使用素地の焼成過程について速度論的な考察を行い， 両素地を比較し, 更に微構造と焼成素地の物性変化の関 係についてあわせ検討した。

両素地の間には結晶相生成の過程に差が認められた が， $1200^{\circ} \mathrm{C}$ 以上の焼き締りの過程は類似しており，得 られた素地も類似した結晶相と物性を示すことが明らか にできたのでその結果について報告する。

\section{2. 実験方法}

\section{1 試料}

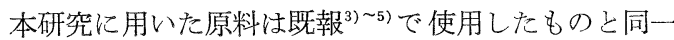
の骨リン，赤坂石灰石，十勝カオリン，振草セリサイト， 村上粘土, 瀬戸蛙目 (がいろめ) 粘土, 中国午石, イ ンド長石である。骨灰は牛骨の仮焼物の粉砕物 ${ }^{2)}$ で化学 分析值は表 1 に示した。

試験試料は各原料をひよら量混合し表 1 亿示した組成 の素地配合物を調製した。A，B，C素地は骨リンを使用 し，D素地は骨灰を使用した素地である。それぞれの素 地配合物は $5 \%$ （重量比）のパラフィンを混合し，10火 $80 \times 5.5( \pm 0.3) \mathrm{mm}$ を金型で $1000 \mathrm{~kg} / \mathrm{cm}^{2}$ の乾式プレ ス成形し試験片とした．透光度測定用試料は別途に $\phi 30$ $\times 2 \mathrm{~mm}$ を金型で $1000 \mathrm{~kg} / \mathrm{cm}^{2}$ の乾式プレス成形した.

\section{2 実験方法}

2.2.1 熱膨張収縮の測定成形試験片を用いて昇 温熱膨張収縮を $10^{\circ} \mathrm{C} / \mathrm{min}$ の昇温速度で室温から測定し

Table 1. Chemical composition of bone china bodies and bone ash (fired at $1240^{\circ} \mathrm{C}$ for $1 \mathrm{~h}$ ).

\begin{tabular}{|c|c|c|c|c|c|}
\hline & Bone ash & A-Body & B-Body & C-Body & D-Body \\
\hline $\mathrm{SiO}_{2}$ & 0.45 & 35.77 & 33.36 & 36.29 & 36.84 \\
\hline $\mathrm{TiO}_{2}$ & 0.01 & 0.21 & 0.21 & 0.18 & 0.34 \\
\hline $\mathrm{Al}_{2} \mathrm{O}_{3}$ & 0.13 & 15.60 & 15.56 & 15.49 & 17.84 \\
\hline $\mathrm{Fe}_{2} \mathrm{O}_{3}$ & 0.01 & 0.43 & 0.48 & 0.46 & 0.29 \\
\hline $\mathrm{P}_{2} \mathrm{O}_{5}$ & 41.10 & 18.75 & 20.27 & 18.79 & 17.79 \\
\hline $\mathrm{CaO}$ & 54.50 & 26.45 & 27.34 & 25.95 & 23.13 \\
\hline $\mathrm{MgO}$ & 0.75 & 0.38 & 0.37 & 0.37 & 0.60 \\
\hline $\mathrm{K}_{2} \mathrm{O}$ & 0.30 & 1.69 & 1.59 & 1.79 & 2.44 \\
\hline $\mathrm{Na}_{2} \mathrm{O}$ & 1.60 & 0.39 & 0.36 & 0.34 & 0.81 \\
\hline Ig. loss & 1.11 & 0.36 & 0.33 & 0.32 & 0.24 \\
\hline Total & 99.96 & 100.03 & 99.87 & 99.98 & 100.32 \\
\hline
\end{tabular}

た. 更に $700^{\circ} \mathrm{C} ， 30$ 分仮焼した試験片を用いて 890 $950^{\circ} \mathrm{C}$ 間の等温収縮を測定した。また $1000^{\circ} \mathrm{C}, 30$ 分仮 焼した試験片を用いて $1170 \sim 1245^{\circ} \mathrm{C}$ 間の等温収縮を測 定した.

2.2.2 反応率の測定 骨リン使用素地 (A素地) と 骨灰使用素地 ( D 素地) について 900 960 ${ }^{\circ} \mathrm{C}$ 間におけ る $\mathrm{Ca}_{3}\left(\mathrm{PO}_{4}\right)_{2}$ とアノーサイトの生成率を $\mathrm{X}$ 線回折の内 部標準法 ( $\mathrm{Si}$ 使用) を用いて測定し, 反応率を求めた. 標準物質及び検量線 $\left(\right.$ 既報 $^{6)}$ と同一のものを使用し，試 験方法も準拠した.

2.2 .3 焼成試料の物性測定 $\quad 1220 \sim 1250^{\circ} \mathrm{C}$ 間の各 温度で所定時間保持し，焼成した各々の試験片について かさ比重, 共振法によるたわみ弾性率, 万能試験機によ る抗折強度, 光透過法による透光度, 膨張係数を測定し, 焼成温度と保持時間による変化を調べた。また偏光顕微 鏡, 走查型電子顕微鏡の観察とX線回折を行い, 微構造 変化との関係も調べた.

\section{3. 結果}

\section{1 収縮過程と反応率}

$\mathrm{A}, \mathrm{B}, \mathrm{C}, \mathrm{D}$ の各素地の昇温熱膨張収縮を測定し，そ の結果を図 1 に示した.この図から各素地とも $920^{\circ} \mathrm{C}$ 付 近と $1200^{\circ} \mathrm{C}$ 付近に収縮を示す特徵が認められた.この 結果をもとに $890 \sim 950^{\circ} \mathrm{C}$ 間の等温収縮を測定し，更に その結果を両対数プロットし，A 素地について図 2, 3 に示した. また $\mathrm{A}, \mathrm{B}, \mathrm{C}, \mathrm{D}$ の各素地の $920^{\circ} \mathrm{C}$ の等温 収縮の雨対数プロットを図 4 に示した。両対数プロット

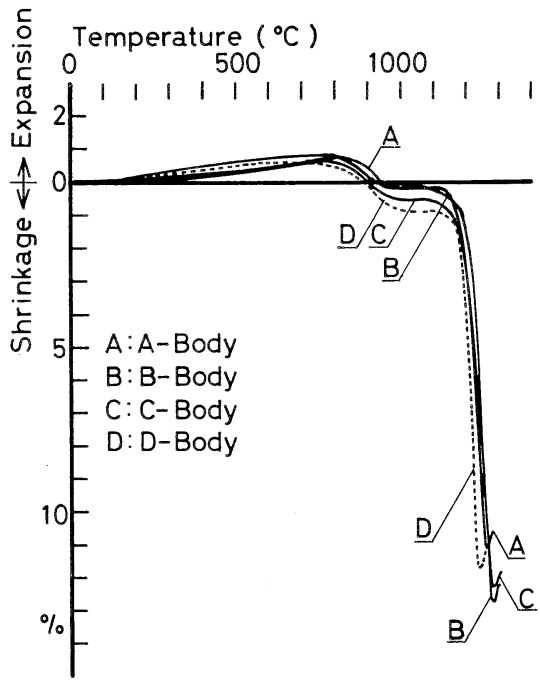

Fig. 1. Thermal expansion and shrinkage curves of bone china bodies. 
仙いずれも良い直線関係を示し，傾向も類似していた。 すなわち等温収縮率 $\Delta l / l_{0}$ と保持時間 $t$ との間に $\left(\Delta l / l_{0}\right)^{P}$ $=B^{\prime} t$ の関倸が存在し，この直線のこう配は $920^{\circ} \mathrm{C}$ 付近 では $0.21 〜 0.36$ の範囲であった. 更にこの収縮過程に

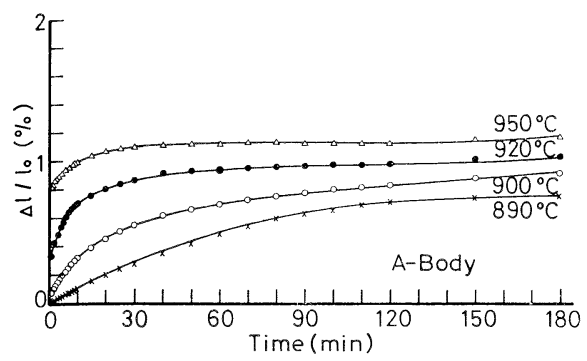

Fig. 2. Isothermal shrinkage curves of bone china body of using bone phosphate at $890 \sim 950^{\circ} \mathrm{C}$.

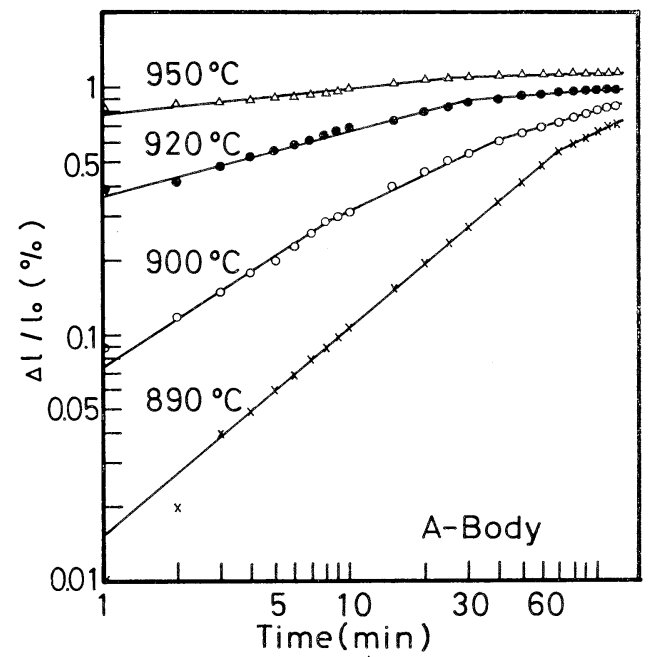

Fig. 3. $\log \Delta l / l_{0}-\log t$ of bone china body of using bone phosphate at $890 \sim 950^{\circ} \mathrm{C}$.

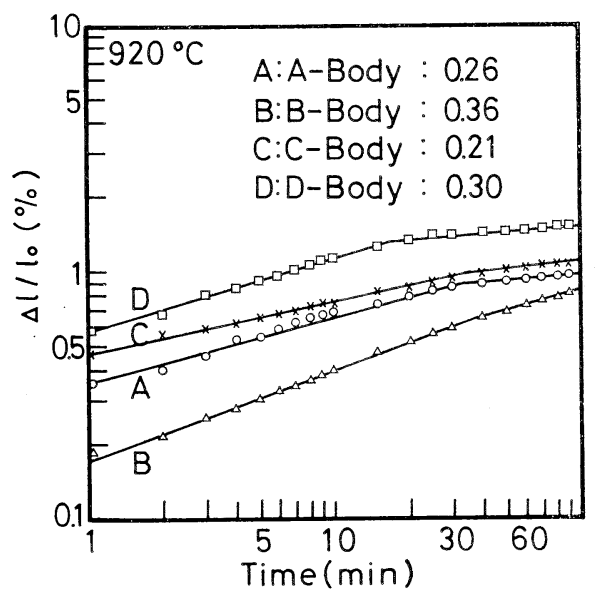

Fig. 4. $\log \Delta l / l_{0}-\log t$ of bone china bodies at $920^{\circ} \mathrm{C}$.

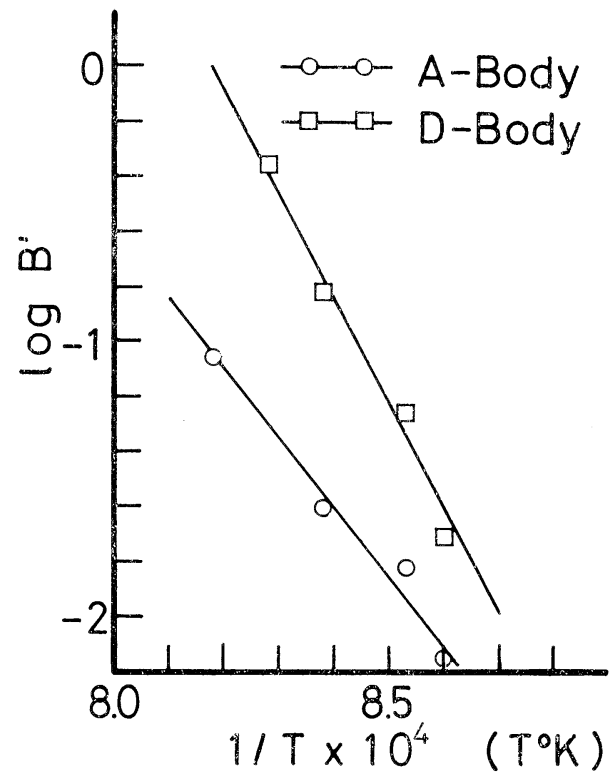

Fig. 5. Arrhenius plots for shrinkage process occurred around $920^{\circ} \mathrm{C}$ of bone china bodies.

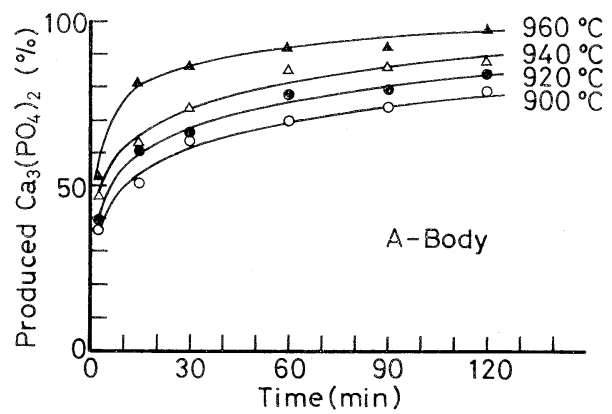

Fig. 6. Relation between the firing time and quantity of produced $\mathrm{Ca}_{3}\left(\mathrm{PO}_{4}\right)_{2}$ in bone china body of using bone phosphate at $900 \sim 960^{\circ} \mathrm{C}$.

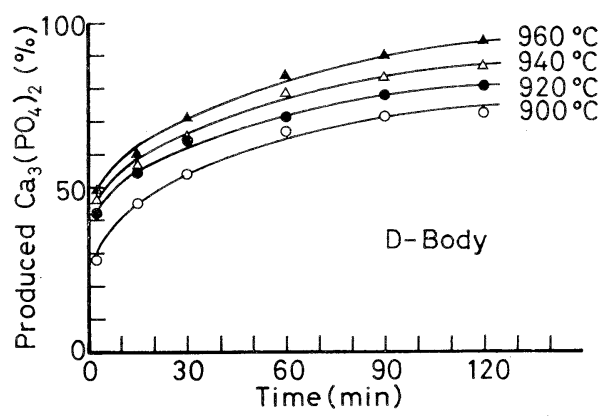

Fig. 7. Relation between the firing time and quantity of produced $\mathrm{Ca}_{3}\left(\mathrm{PO}_{4}\right)_{2}$ in bone china body of using bone ash at 900 $960^{\circ} \mathrm{C}$. 
ついて $\mathrm{A}$ 素地と D 素地の速度定数を算出し Arrhenius プロットをすると図 5 のように直線関係が得られた。こ の関係から見掛けの活性化エネルギーを算出すると，A 素地は $109 \mathrm{kcal} / \mathrm{mol}, \mathrm{D}$ 素地は $173 \mathrm{kcal} / \mathrm{mol}$ となった。

またこの収縮過程に対応する素地内の反応として既 報6)の結果から $\mathrm{Ca}_{3}\left(\mathrm{PO}_{4}\right)_{2}$ とアノ一サイドの生成反応が 考えられるので，A素地と D素地について反応率と見掛 けの活性化エネルギーを求めて図 6,7 亿反度率の測定 結果の一部と, 図 8 に速度定数の Arrhenius プロットを 示した。見掛けの活性化エネルギーを計算すると， $\mathrm{A}$ 素 地の $\mathrm{Ca}_{3}\left(\mathrm{PO}_{4}\right)_{2}$ の生成は $58 \mathrm{kcal} / \mathrm{mol}$, アノーサイトの 生成は $138 \mathrm{kcal} / \mathrm{mol}, \mathrm{D}$ 素地の $\mathrm{Ca}_{3}\left(\mathrm{PO}_{4}\right)_{2}$ の生成は 42

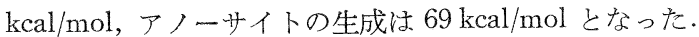

図 1 から $1200^{\circ} \mathrm{C}$ 付近にもら一つの大きな収縮が認め られ，1170 $1245^{\circ} \mathrm{C}$ 間の等温収縮を測定した. 図 9,10 にA素地の測定結果と両対数プロットを示した. A,B, $\mathrm{C}, \mathrm{D}$ の各素地の $1200^{\circ} \mathrm{C}$ の等温収縮の両対数プロット は図 11 に示した。雨対数プロットはいずれも良い直線 関係を示し，直線のこう配は $1200^{\circ} \mathrm{C}$ 付近では 0.43 0.68 の範囲であった. 更に収縮過程について速度定数 を算出し Arrhenius プロットすると図 12 のよらに直線 関係が得られた。この関係から見掛けの活性化エネルギ 一を求めると，A 素地は $504 \mathrm{kcal} / \mathrm{mol} ， \mathrm{D}$ 素地は 603 $\mathrm{kcal} / \mathrm{mol}$ となった。

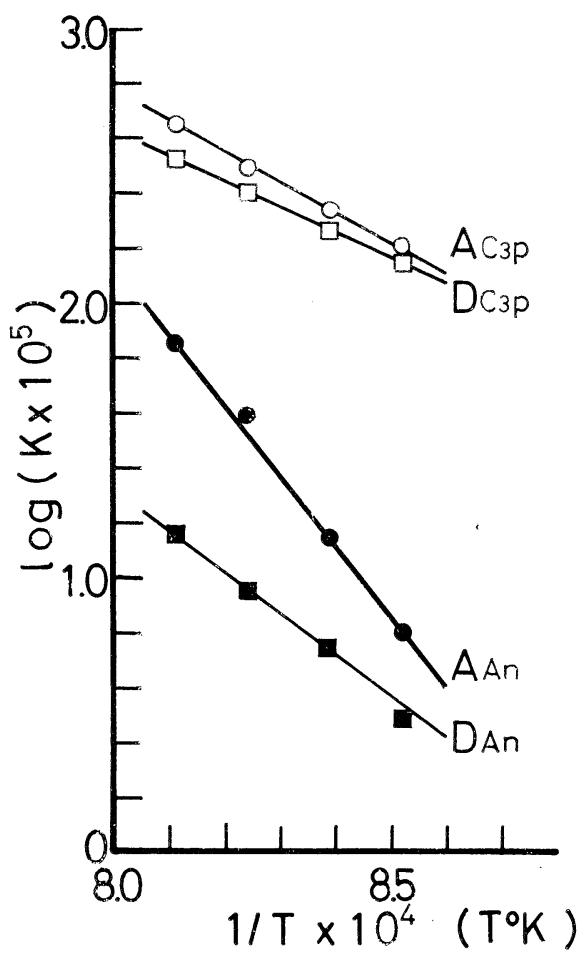

Fig. 8. Arrhenius plots of velocity constant of reaction occurred around $920^{\circ} \mathrm{C}$ for bone china bodies.

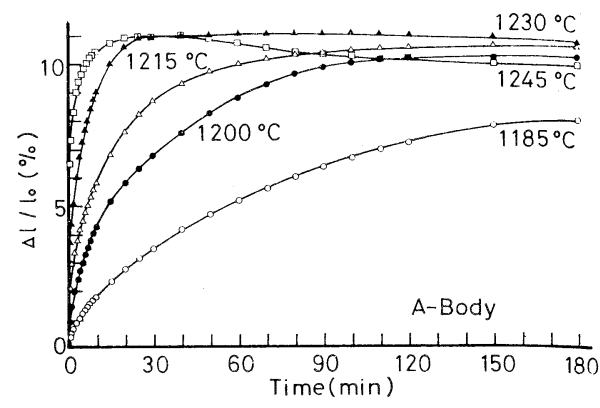

Fig. 9. Isothermal shrinkage curves of bone china body of using bone phosphate at $1185 \sim 1245^{\circ} \mathrm{C}$.

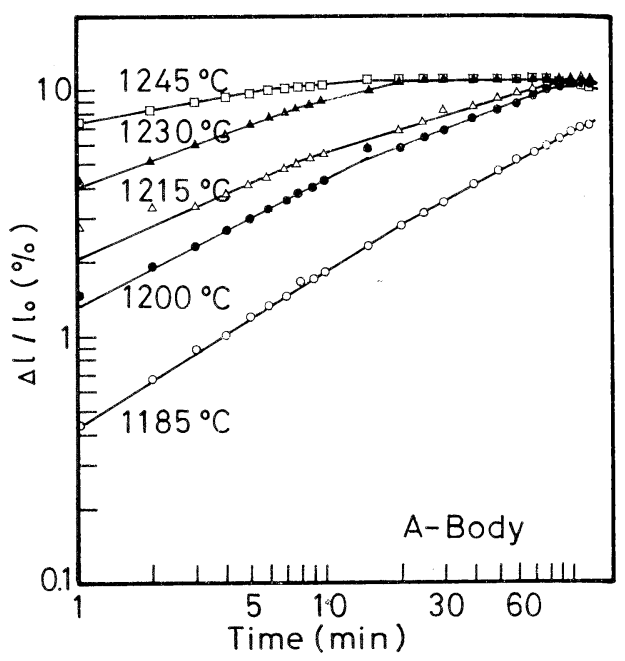

Fig. 10. $\log \Delta l / l_{0}-\log t$ of bone china body of using bone phosphate at $1185 \sim 1245^{\circ} \mathrm{C}$.

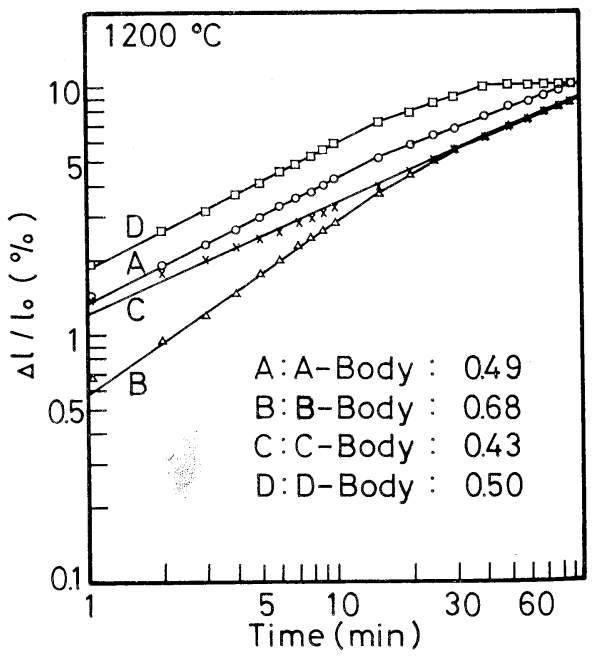

Fig. 11. $\log \Delta l / l_{0}-\log t$ of bone china bodies at $1200^{\circ} \mathrm{C}$. 


\section{2 焼成試料の物性測定}

$1200^{\circ} \mathrm{C}$ 以上の素地の 焼き締り度合と微構造と諸物性 の関係を調べたＡ素地と D 素地の成形試験片を電気 炉中で $10^{\circ} \mathrm{C} / \mathrm{min}$ で昇温し, 所定の温度と時間に到達 後，炉中で放冷したものを種々の測定に供した。

各々の測定結果は骨リン使用の $\mathrm{A}$ 素地と骨灰使用の $\mathrm{D}$ 素地を比較して, 図 13 亿かさ比重の測定結果を示した。 焼成温度の上昇と保持時間の延長江伴い值が小さくなる 傾向が認められた。 図 14，15 亿弹性率と抗折強度の測 定結果を示した.いずれも類似した傾向を示し，焼成温度 の上昇と保持時間の延長に伴い值が小さくなっている。 図 16 亿透光度の測定結果を示した。透光度は透過率 $T$ $\left(T=I / I_{0}\right.$, (入射光 : $I_{0}$, 透過光 $\left.: I\right)$ ) を測定し, 単位厚 さ $(1 \mathrm{~mm})$ の透光度 $\delta$ を Goodman ${ }^{7)}$ による関係式から $\log \delta=\log T / d$ (試料厚さ $: d \mathrm{~mm}$ ) により算出した. 焼 成温度の上昇と保持時間の延長に伴い大きくなる傾向が

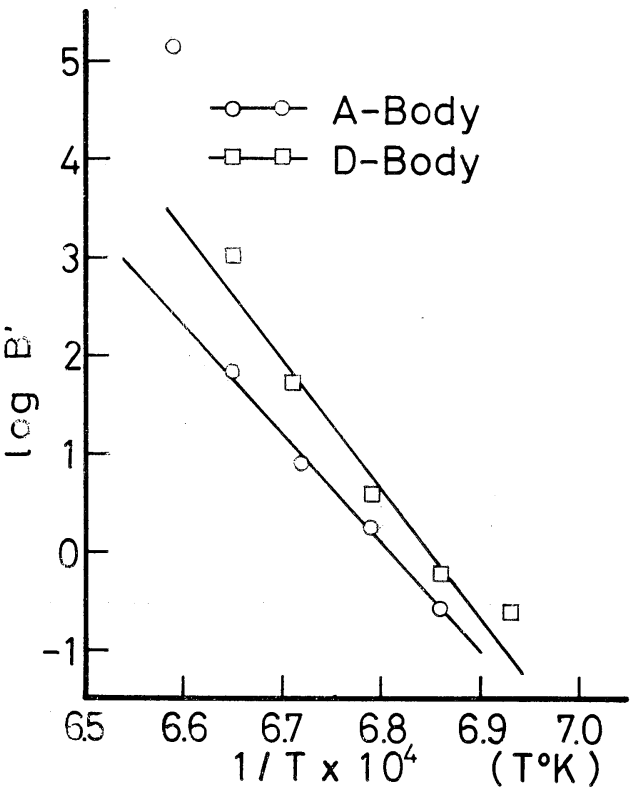

Fig. 12. Arrhenius plots for shrinkage process occurred around $1200^{\circ} \mathrm{C}$ of bone china bodies.

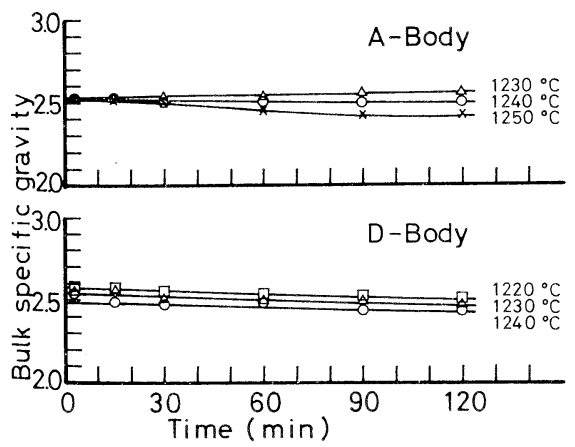

Fig. 13. Bulk specific gravity of fired bodies.

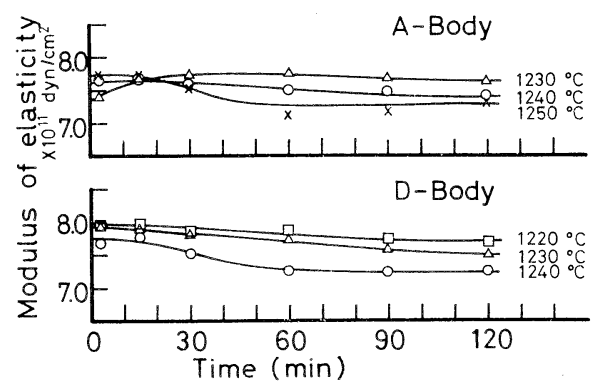

Fig. 14. Modulus of elasticity of fired bodies.

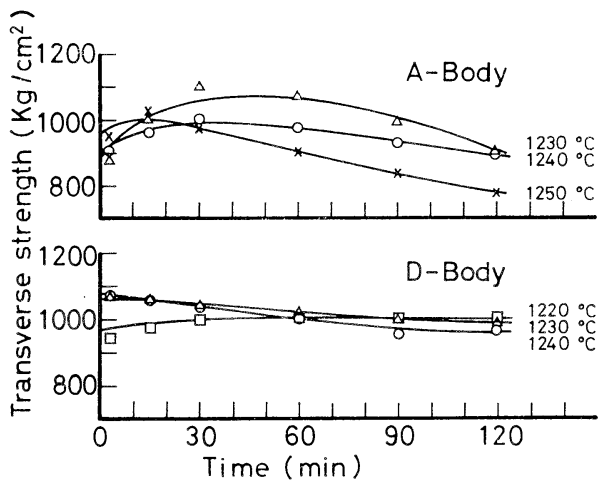

Fig. 15. Transverse strength of fired bodies.

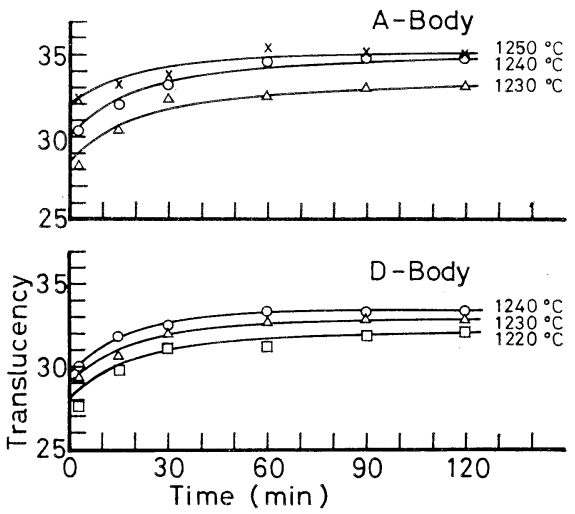

Fig. 16. Translucency of fired bodies.

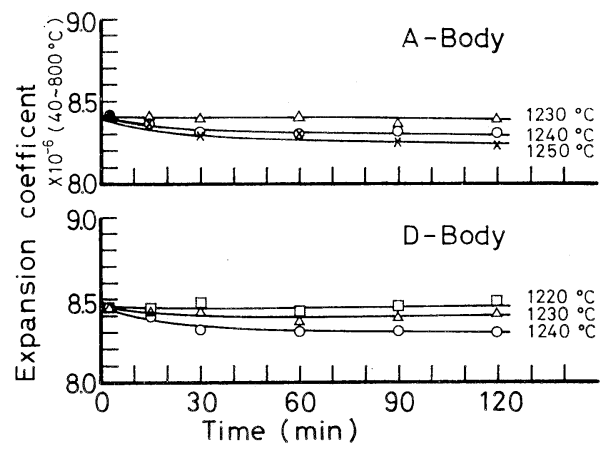

Fig. 17. Expansion coefficient of fired bodies. 
認められた。図 17 に燒成素地の膨張係数の測定結果を 示した．焼成温度の上昇と保持時間の延長に伴い值が小 さくなっていく傾向が認められた. 図 18，19に偏光顕 微鏡と走查型電子顕微鏡の写真を示した. 焼成温度の上 昇に伴いマトリックス部のガラス質の増加と結晶質部の 微細均一化が偏光顕微鏡写真に認められ，また気孔のわ ずかな拡大の傾向が 走査型電子顕微鏡写真で認められ た.X線回折図にはいずれの試料の結果にも顕著な変化 及び比較差は認められなかった。

\section{4. 考察}

\section{1. $920^{\circ} \mathrm{C}$ 付近の焼成過程}

ボーンチャイナ素地の昇温熱膨張収縮の測定結果を図 1 に見ると $920^{\circ} \mathrm{C}$ 付近と $1200^{\circ} \mathrm{C}$ 付近に収縮を示す特 徴がある．カオリン質素地に見られる $500^{\circ} \mathrm{C}$ 付近の収 縮がカオリンを使用しているにもかかわらず認められな いのも特幑であるが，これは長石，骨リン，石灰石によ る膨張で収縮が吸収された結果と推定できる ${ }^{8)}$.

$920^{\circ} \mathrm{C}$ 付近の収縮について等温収縮の測定によって検

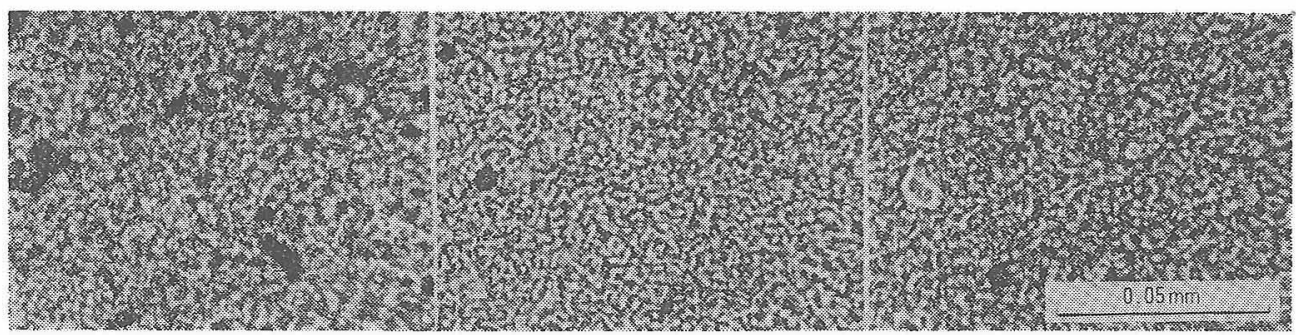

$\mathrm{A} 1: 1230^{\circ} \mathrm{C}, 30 \mathrm{~min}$

A $2: 1240^{\circ} \mathrm{C}, 30 \mathrm{~min}$

A $3: 1250^{\circ} \mathrm{C}, 30 \mathrm{~min}$

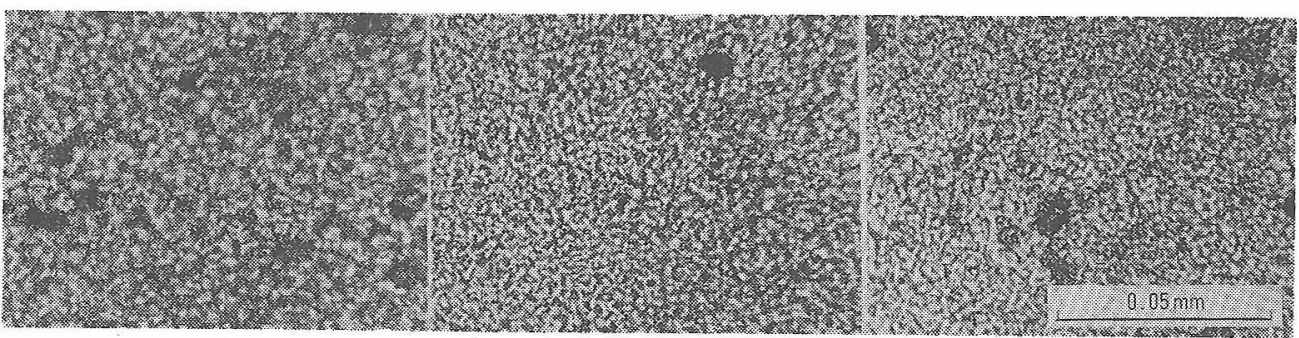

$\mathrm{D} 1: 1220^{\circ} \mathrm{C}, 30 \mathrm{~min}$

$\mathrm{D} 2: 1230^{\circ} \mathrm{C}, 30 \mathrm{~min}$

D3 : $1240^{\circ} \mathrm{C}, 30 \mathrm{~min}$

Fig. 18. Polarization microphotographs of bone china bodies. A1, A 2, A 3 : A-Body D 1, D 2, D 3 : D-Body

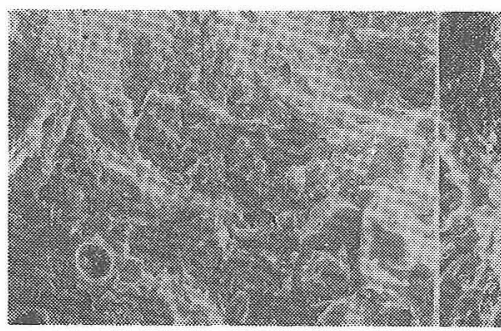

A $1: 1230^{\circ} \mathrm{C}, 30 \mathrm{~min}$

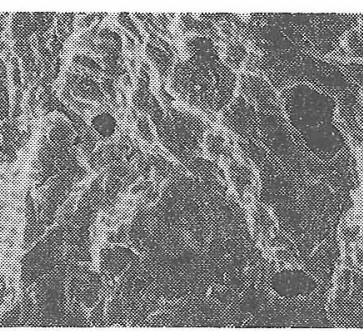

A $2: 1240^{\circ} \mathrm{C} 30 \mathrm{~min}$

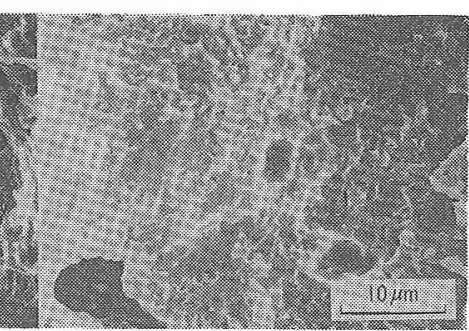

A $3: 1250^{\circ} \mathrm{C}, 30 \mathrm{~min}$

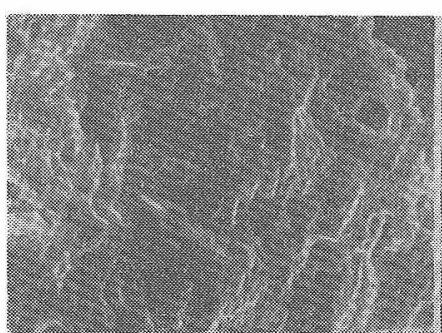

$\mathrm{D} 1: 1220^{\circ} \mathrm{C}, 30 \mathrm{~min}$

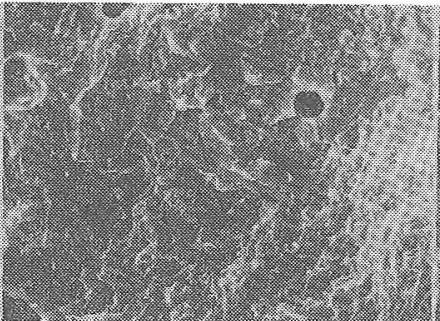

$\mathrm{D} 2: 1230^{\circ} \mathrm{C}, 30 \mathrm{~min}$

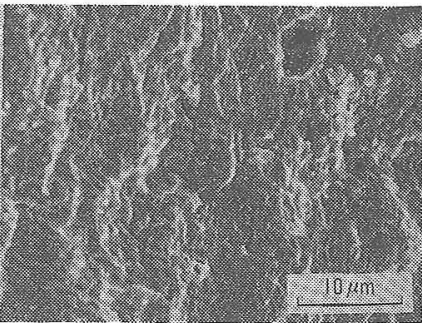

D3 : $1240^{\circ} \mathrm{C}, 30 \mathrm{~min}$

Fig. 19. Scanning electron microphotographs of bone china bodies. A 1, A 2, A 3 : A-Body D 1, D 2, D 3 : D-Body 
討する一方，素地中の反応について検討した。 反忘は $\mathrm{Ca}_{3}\left(\mathrm{PO}_{4}\right)_{2}$ とアノーサイトの生成が行われていることは 既に明らかにされているので) (6)，骨リン使用のA素地 と骨灰使用の D 素地について結晶相生成過程について $\mathrm{Ca}_{3}\left(\mathrm{PO}_{4}\right)_{2}$ とアノーサイトの反応率を測定してその機作 至検討した。測定から得られた反応率と時間を Jander の式に応用したところ直線性が得られ, 拡散過程が律速 になる反応が推定できた ${ }^{6)}$. 見掛けの活性化エネルギー を比較すると $\mathrm{A}$ 素地の $\mathrm{Ca}_{3}\left(\mathrm{PO}_{4}\right)_{2}$ とアノーサイトの生 成反応と収縮過程に対する值に相互関係を認めることが できたが，D素地には同様の相互関係は認め難く,むしろ この場合の収縮過程については浜野らの報告しているメ タカオリンの粒界拡散機構による収縮過程の測定值 ${ }^{8}$ に 近い值を示し, 水酸アパタイトの分解による $\mathrm{Ca}_{3}\left(\mathrm{PO}_{4}\right)_{2}$ とアノーサイトの生成反忘の值とは差が大きいと考えら れる. 寸なわち $\mathrm{A}$ 素地では石灰成分の扰散による $\mathrm{Ca}_{3}-$ $\left(\mathrm{PO}_{4}\right)_{2}$ とアノーサイトの生成に律速される素地の収縮 過程が推測できるが，D素地では水酸アパタイトの分解 による石灰成分の拡散によるアノーサイトの生成とメタ カオリンの粒界拡散の複合した素地の収縮過程が推測で きる。

\section{$4.21200^{\circ} \mathrm{C}$ 付近の焼成過程}

ボーンチャイナ素地の $1200^{\circ} \mathrm{C}$ 付近の収縮は急速で, かつ大きい特徴がある。この収縮過程を等温収縮の測定 によって検討した。各素地の測定から得られた収縮率と 時間との両対数プロットの直線のこう配は $0.43 \sim 0.68$ の值を示した，焼成素地を偏光顕微鏡下で観察すると溶 融物が生成していることが認められ，溶融物による粘性 流動機構による収縮過程が推測できるのであるが，等温 収縮測定の結果による直線のこう配は 1 亿ならず，完全 な粘性流動機構による収縮過程注考光難( ${ }^{8), 99}$. 図 16 , 17,18 の透光度, 膨張係数, 偏光顕微鏡写真から結晶物 の溶解が認められ, 特に $\mathrm{Ca}_{3}\left(\mathrm{PO}_{4}\right)_{2}$ の溶解が膨張係数 の減少現象から推測でき, これらの溶融液内一の溶解が 考えられる。また偏光顕微鏡観察から推定したマトリッ クス部の溶融液の増加速度から, この素地中の結晶物の 溶融液への溶解速度はかなりの急速度で, 素地の焼き締 り過程にも大きく作用していると推測できる ${ }^{8)}$. したが って $1200^{\circ} \mathrm{C}$ 付近の収縮過程は溶融液生成に伴ら粘性流 動機構も考えられ, また溶解過程も考えられ, 両者の複 合によるものと推測できる.

$1230^{\circ} \mathrm{C}$ 付近になると素地の等温収縮は保持時間の延 長に伴い逆に膨張を示す傾向が認められた．偏光䫓微鏡 の観察ではマトリックスの溶融液の増加は認められる が，再結晶化及び結晶の成長注認められず，また走查型 電子顕微鏡の観察によれば素地中の気孔が膨張して大き くなっている傾向が認められる．素地のわずかな膨張の 傾向はこの気孔の発達が作用した結果であると推測でき
万.

\section{3 焼成過程亡物性変化}

$1200^{\circ} \mathrm{C}$ 付近以上で起こる急速な収縮による素地の燒 き締り過程について微構造と物性変化の関係を検討し た. $1220 \sim 1250^{\circ} \mathrm{C}$ の焼成素地は 偏光顕微鏡下では燒成 温度が上昇するに伴いマトリックス部のガラス質が発達 していることが観察された（図 18）。 また走査型電子顕 微鏡による観察では温度上昇による素地のら密化と同時 に気孔の膨張が認められた（図 19）。 また保持時間の延 長によっても同様の傾向が認められ, 素地の微構造は温 度の上昇と保持時間の延長に伴いマトリックス部のガラ 不質の増加とそれに伴らち密化が進行すると同時に気孔 の発達も徐々に進行し, 素地全体としては図 13 に見ら れるようにかさ比重の低下が進み，いわゆる過焼成の状 態へと進行することが推測できる。弾性率, 抗折強度の 測定結果もこの微構造の変化を反映し ${ }^{10)}$ 12), 弾性率は マトリックス部のガラス質が均一に増加している間は増 大し, 気孔の発達が顥著に進行するとガラス質の増加に もかかわらず減少を始めた．抗折強度は素地のち密化之 ガラス質の発達に伴い増大し, やはり気孔の発達と同時 に減少を始める傾向を示した。

透光度は，素地中に均質にガラスが発達すると増加 し ${ }^{13), 14)}$, 更にボーンチャイナ素地の場合, ガラス相に リン成分が富化すると結晶とガラスとの屈折率の差が改 善され, 更に透光度が増加する傾向がある ${ }^{15)}$. 本実験の 場合もよく一致した傾向を示し, 気孔の発達にもかかわ らず温度上昇と保持時間延長に伴い増加を示した。

膨張係数は結晶の溶解により隇少し, 特に高膨張結晶 の $\mathrm{Ca}_{3}\left(\mathrm{PO}_{4}\right)_{2}$ の溶解が影響しているようである.しか しこの結晶の溶解は X線回折に顕著な減少が示されてい ないことから溶解量はわずかであることが推定できる。 偏光顕微鏡の観察で見られるマトリックス部のガラス質 の発達は，他の組成物から生成した溶融液とその抬散に よる均一化による現象が主であると推測できる。

素地の焼成温度と物性值の変化を検討した場合, 上述 した考察からボーンチャイナ素地の焼成は最大収縮温度 で短時間に焼成するのは良い方法でなく，若干低温度で 保持時間を長くする焼成方法が良い物性值を示すと推測 できる。

\section{4 骨リン式素地と骨灰式紊地の比較}

骨リンを使用した素地（A素地）と骨死を使用した素 地（D 素地）を比較すると 4.1 で述べたように $920^{\circ} \mathrm{C}$ 付近の結晶相生成の過程に大きな差異が認められるが, その他の焼成過程に本質的な差異は認められなかった。 すなおち $1200^{\circ} \mathrm{C}$ 以上の焼成過程においては組成の違い による最大収縮温度の差にもとづく差以上の差は認为難 く, 収縮過程の見掛讨の活性化エネルギ一や諸物性值の 変化の傾向は同一であった. また素地組成\& $\beta-\mathrm{Ca}_{3}\left(\mathrm{PO}_{4}\right)_{2}$ 
とアノーサイトとガラス相で同一であることが確認でき た.ただ物性值の絶体值については抗折強度, 透光性に 若干の差が認められ，骨りン使用素地の方がやや優れた 值を示したが，これはマトリックス部のガラス質の発達 の差によるものと推測される。

\section{5. 総括}

骨リンを使用したボーンチャイナ素地の焼成過程を検 討し，あわせて骨灰使用素地の焼成過程と比較検討し た。得られた結果を要約すると次のとおりである.

(1) 素地は $920^{\circ} \mathrm{C}$ 付近と $1200^{\circ} \mathrm{C}$ 付近で収縮し, $920^{\circ} \mathrm{C}$ 付近は $\mathrm{Ca}_{3}\left(\mathrm{PO}_{4}\right)_{2}$ とアノーサイトの生成を主と した収縮過程である。

（2） $1200^{\circ} \mathrm{C}$ 付近は融液生成による素地のマトリッ クス部のガラス相の発達に伴ら収縮過程であり, 粘性流 動機構と結晶溶解過程の複合した収縮過程が推測でき た.

（3） $1200^{\circ} \mathrm{C}$ 以上の素地の焼き締り過程により焼成 素地の物性が特徵ゔけられるが, その主な要素はガラス 質の生成条件によって律せられる。すなわち弾性率はガ ラス質が素地マトリックス中に均質に発達すれば大きく なるが，素地中の気孔の発達により，ガラス質の増加に もかかわらず小さくなる.抗折強度は素地のち密化とガ ラス質の発達によって大きくなるが，素地中の気孔の発 達により小さくなる。透光度はガラス質の均一発達によ り大きくなり，わずかな気孔の発達は影響がないことが わかった. また素地中の $\mathrm{Ca}_{3}\left(\mathrm{PO}_{4}\right)_{2}$ の結晶が溶解し減 少すると膨張係数は小さくなる傾向があることが明らか にできた。

（4）素地の焼成は燒成収縮 及び物性変化の傾向か ら, 最大収縮温度加ら若干低く, 保持時間を長くする焼 成方法が良い素地物性が得られることがわかった。

（5）骨リン使用素地と骨灰使用素地は $920^{\circ} \mathrm{C}$ 付近
の結晶相生成の過程が骨リン使用の場合はピロリン酸カ ルシウムに石灰石からの石灰成分が反応して $\mathrm{Ca}_{3}\left(\mathrm{PO}_{4}\right)_{2}$ を生成し，また同様にケイ酸塩鉱物と反応してアノ一曲 イト学生成するのに対して，骨灰使用の場合は水酸アパ タイトの分解により $\mathrm{Ca}_{3}\left(\mathrm{PO}_{4}\right)_{2}$ が生成し, 分解生成し た石灰成分とケイ酸塩鉱物が反応してアノーサイトを生 成するといらように異なっており, 素地の収縮過程もそ の影響を受けていると推測できた. $1200^{\circ} \mathrm{C}$ 付近の収縮 過程は両素地に顕著な差は認められなかった。したがっ て焼成素地㵟構造的にも物性変化も類似した傾向を示 した。

謝辞 本研究に発表の機会をいただいた鳴海製陶 石原洌専務取締役はじめ関係の方《に感謝の意を表します。 た研究をまこめるにあたり 終始御指導学賜わりました東京工業 大学工業材料研究所浜野健也教授に心加ら感謝し安す. 更に研 究遂行にあたって御助言を賜わりました東京都立大学工学部金 沢孝文教授，また御協力を賜わりました鳴海製陶湖研究室の方 々に感謝の意它表します。

\section{文献}

1) W.A. Weyl, J. Am. Ceram. Soc., 24, 245-47 (1941).

2) P.D.S.St. Pierre, J. Am. Ceram. Soc., 38, 217-22 (1955).

3）市古忠利, 割協, 84, 185-93 (1976).

4）市古忠利, 磯野趐夫, 望月敬一, 窐協, 85, 1-8 (1977).

5）市古忠利, 磯野起夫, 望月敬一, 窝協, 85, 218-25(1977).

6) 市古忠利, 石膏之石兏 [152] 3-7 (1978).

7) G. Goodman, J. Am. Ceram. Soc., 33, 66-72 (1950).

8）浜野健也，李応相，筧協，81，64-76 (1973).

9) W.D. Kingery, J. Appl. Phys., 30, 301-06 (1959).

10) A. Dinsdale and W.T. Wilkinson, Proc. Brit. Ce. ram. Soc., 6, 119-39 (1966).

11）浜野健也，表面，12，503-17 (1974).

12）浜野健也，エレクトロニクセラミクス， [1] 25-34 (1975).

13）野口長次，浜野健也，賨協，60，181-84（1952）.

14）野口長次, 浜野健也, 㝘協, 60, 309-12 (1952).

15）野田稲吉, 稲田 博, 深沢 力, 葖協, 66, 91-97 (1958).

論文・Paper

\title{
Microvoids in Pitch-based and Lignin-based Carbon Fibres as Observed by X-ray Small-angle Scattering
}

\author{
Isao TOMIZUKA and David J. JOHNSON**
}

(National Research Institute for Metals, Meguro-ku, 153

* Department of Textile Industries, University of Leeds, England) 